\title{
Time-resolved $A_{x}$-luminescence of Nal:TI under electron pulse irradiation
}

\author{
V.Yakovlev $^{1}$, L.Trefilova $^{2}$, V.Alekseev $^{3}$, V.Krasnov $^{3}$ \\ ${ }^{1}$ Tomsk Polytechnic University, \\ 30 Lenin Ave., 634034 Tomsk, Russian Federation \\ ${ }^{2}$ National University of Civil Protection, \\ 94 Chernyshevska Str., 61023 Kharkiv, Ukraine \\ ${ }^{3}$ Institute for Scintillation Materials, STC "Institute for Single Crystals", \\ National Academy of Sciences of Ukraine, \\ 60 Nauky Ave., 61001 Kharkiv, Ukraine
}

\section{Received April 17, 2016}

This paper studies spectral-kinetic properties of Nal:Tl cathodoluminescence registered in the region of $A_{x}$-band with maximum $425 \mathrm{~nm}$ within the time interval of $10^{-8}-10^{-2} \mathrm{~s}$. $A_{x}$-luminescence of Nal:Tl crystal has been excited with an electron pulse $\left(E_{e}=0.25 \mathrm{MeV}, t_{1 / 2}\right.$ $=10 \mathrm{~ns}, W=0.003 \ldots 0.16 \mathrm{~J} / \mathrm{cm}^{2}$ ) at temperatures in the range of $65-300 \mathrm{~K}$. It has been found that the cathodoluminescence kinetics of Nal:TI crystal at $425 \mathrm{~nm}$ has beside the exponential decay ( $\tau=235 \mathrm{~ns}$ at $T=295 \mathrm{~K}$ ) also three more components: the fastest exponential decay $(\tau=12$ ns at $T=78 \mathrm{~K})$, post-irradiation rise on a submicrosecond time scale at $T \geq 128 \mathrm{~K}$ and slow exponential decay at $T \geq 160 \mathrm{~K}$. A model has been suggested according to which $A_{x}$-luminescence at $425 \mathrm{~nm}$ is caused by ${ }^{1} P_{1} \rightarrow{ }^{1} S_{0}$ electron transition of $\mathrm{Tl}^{+}$ion. It has been explained that the fast decay and post-irradiated rise components are caused by ${ }^{3} P_{1} \rightarrow{ }^{1} P_{1}$ and ${ }^{3} P_{0} \rightarrow{ }^{3} P_{1}$ electron transitions of $\mathrm{Tl}^{+}$ion, respectively. The scintillation process in Nal:Tl has been discussed.

Keywords: Thallium-doped sodium iodide; time-resolved cathodoluminescence; energy transfer; intra-center transitions.

Исследованы спектрально-кинетические свойства $A_{x}$-полосы люминесценции $\mathrm{Nal}: \mathrm{Tl}$ с максимумом 425 нм во временном интервале $10^{-8}-10^{-2}$ с. $A_{x}$-люминесценция кристалла Nal:TI возбуждалась импульсом электронов $\left(E_{e}=0,25 \mathrm{MeV}, t_{1 / 2}=10 \mathrm{Hc}, W=\right.$ $0,003 \ldots 0,16 \mathrm{~J} / \mathrm{cm}^{2}$ ) в температурном интервале $65-300 \mathrm{~K}$. Установлено, что в кинетике импульса катодолюминесценции, что регистрируется в области 425 нм, кроме экспоненциального компонента затухания ( $\tau=235$ нс при $T=295 \kappa)$, наблюдается еще три компонента: самый быстрый экспоненциальный компонент затухания с $\tau=12$ нс (при $T=78 \mathrm{~K}$ ), пострадиационный компонент нарастания (при $T \geq 128 \mathrm{~K}$ ) в субмикросекундном диапазоне и медленный экспоненциальный компонент затухания (при $T \geq 160 \mathrm{~K})$. Предложена модель, согласно которой полоса $A_{x}$-люминесценции с максимумом в области 425 нм вызвана ${ }^{1} P_{1} \rightarrow{ }^{1} S_{0}$ әлектронным переходом $\mathrm{Tl}^{+}$-центра. Быстрый компонент затухания и пострадиационный компонент нарастания интерпретируются как обусловленные ${ }^{3} P_{1} \rightarrow{ }^{1} P_{1}$ и ${ }^{3} P_{0} \rightarrow{ }^{3} P_{1}$ әлектронными переходами $\mathrm{TI}^{+}$-центра, соответственно. Обсуждается сцинтилляционный процесс в Nal:TI.

Дослідження $з$ часовим розділенням $A_{x}$-люмінесценції $\mathrm{Nal}: \mathrm{TI}$ при імпульсному електронному опроміненні. В.Яковлєв, Л.Трефілова, В.Алексєєв, В.Краснов.

Досліджено спектрально-кінетичні властивості $A_{x}$-смуги люмінесценції $\mathrm{Nal}: \mathrm{TI}$ з мак- 
симумом 425 нм у часовому інтервалі $10^{-8}-10^{-2}$ с. $A_{x}$-люмінесценція кристала Nal:Tl збуджувалася імпульсом електронів $\left(E_{e}=0,25 \mathrm{MeV}, t_{1 / 2}=10 \mathrm{Hc}, W=0,003 \ldots 0,16 \mathrm{~J} / \mathrm{cm}^{2}\right)$ у температурному інтервалі 65-300 K. Встановлено, що у кінетиці імпульса катодолюмінесценції, що реєструється в області 425 нм, крім експоненціального компонента загасання ( $\tau=235$ нс при $T=295 \mathrm{\kappa})$ спостерігається ще три компонента: найбільш швидкий експоненціальний компонент загасання з $\tau=12$ нс (при $T=78 \mathrm{\kappa}$ ), пострадіаційний компонент наростання (при $T \geq 128 \mathrm{~K}$ ) у субмікросекундному діапазоні $\mathrm{i}$ повільний експоненціальний компонент загасання (при $T \geq 160 \mathrm{~K}$ ). Запропоновано модель, відповідно до якої смуга $A_{x}$-люмінесценції з максимумом в області 425 нм спричинена ${ }^{1} P_{1} \rightarrow{ }^{1} S_{0}$ електронним переходом $\mathrm{Tl}^{+}$-центра. Швидкий компонент загасання $\mathrm{i}$ пострадіаційний компонент наростання інтерпретуються як обумовлені ${ }^{3} P_{1} \rightarrow{ }^{1} P_{1}$ i ${ }^{3} P_{0} \rightarrow{ }^{3} P_{1}$ електронними переходами $\mathrm{Tl}^{+}$-центра, відповідно. Обговорюється сцинтиляційний процес у $\mathrm{Nal}: \mathrm{TI}$.

\section{Introduction}

Nal:TI crystals have been widely applied in the scintillation engineering for more than half a century and therefore intensely investigated to understand the mechanisms behind the formation of $\mathrm{T}^{+}$center scintillations under irradiation [1-9]. In spite of voluminous literature, there are still debatable questions left in the physics of the luminescence phenomena in Nal: $\mathrm{Tl}$ crystals. It is still not clear what processes cause the rise and decay components of the scintillation pulse at room temperature and what is the nature of the state responsible for the Tl-related emission. This paper aims to give answers to the debatable questions by offering the obtained experimental results.

\section{Experimental}

A Nal:Tl boule was grown by the Stockbarger technique in an evacuated quartz ampoule. A sample with dimensions of $10 \times 8 \times 2 \mathrm{~mm}^{3}$ was cleaved from the boule in a dry air box. Tl concentration in the sample was chemically determined and amounted to $2 \cdot 10^{-2} \mathrm{~mol} \%$. The luminescence was excited with an electron pulse $\left(0.250 \mathrm{MeV}, 10 \mathrm{~ns}, 0.003 \ldots 0.16 \mathrm{~J} / \mathrm{cm}^{2}\right)$ generated by a GIN-600 accelerator at temperatures within $65-300 \mathrm{~K}$. The sample was cooled down to $65 \mathrm{~K}$ by evacuating nitrogen vapor from the internal container of the cryostat. The cathodoluminescence pulse was registered by a pulse optical spectrometer equipped with an MDR-3 monochromator, FEU-106 photomultiplier and INSTEK GDS2204 oscilloscope in a spectral range of $350-$ $1100 \mathrm{~nm}$ with a time resolution of $7 \mathrm{~ns}$.

\section{Results}

3.1. Spectra and decay kinetics of the cathodoluminescence at $78 \mathrm{~K}$

Pulse cathodoluminescence spectra of $\mathrm{Nal}: \mathrm{Tl}$ sample right after the electron pulse depletion (1) and in $100 \mathrm{~ns}(2)$ at $78 \mathrm{~K}$ are shown in Fig. 1. One can see that the intensity of the cathodoluminescence after $100 \mathrm{~ns}$ decreases about tenfold without affecting the spectrum which fits a Gaussian with parameters $E_{m}=2.92 \pm 0.005 \mathrm{eV}$ and FWHM $=0.39 \pm 0.005 \mathrm{eV}$. The luminescence of $\mathrm{T}^{+}$centers has a complex decay owing to its varying kinetics throughout nano-, micro- and millisecond time scale. This complex decay is illustrated in Fig. 2 and Fig. 3, where the kinetic curves of $\mathrm{Tl}^{+}$center emission are presented in log and log-log scales, respectively. An oscillogram inserted in Fig. 1 demonstrates the fastest decay component with $\tau=12 \pm 1$ ns.

As for the emission decay kinetics on a microsecond time scale at $78 \mathrm{~K}$, it fits the sum of an exponent and hyperbola (Fig. 2a):

$$
I(t)=I_{1} \cdot e^{(-t / \tau)}+\frac{I_{2}}{(1+\alpha \cdot t)^{2}},
$$

where $I_{1}, I_{2}-$ the exponential and hyperbolic component intensities at $t=0$; $\tau$ and $\alpha-$ time constants.

As we can see in Fig. 2a, the exponential component intensity peak $I_{1}$ is much greater than the hyperbolic component intensity peak $I_{2}$.

\subsection{Temperature dependences}

We found that with an increasing temperature from 65 to $300 \mathrm{~K}$ the time constant of exponential decay of Nal:Tl emission decreases, whereas its intensity $I_{1}$ increases (Fig. 3). Moreover, in the kinetics of the cathodoluminescence pulse at temperatures over $128 \mathrm{~K}$ there appears also a post- 


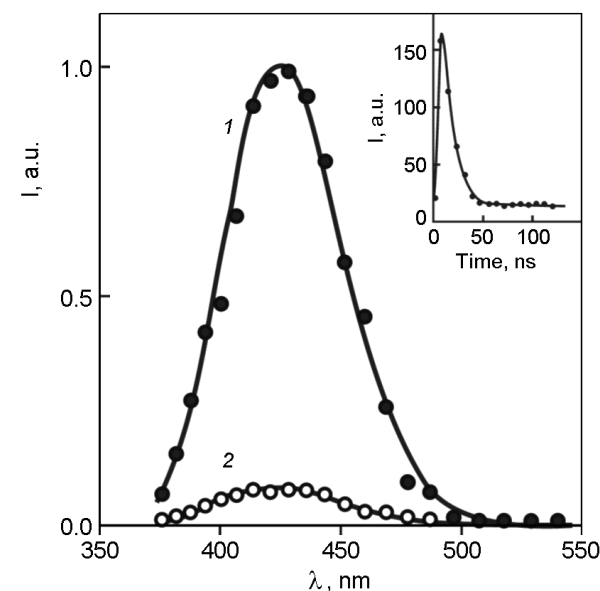

Fig. 1. Cathodoluminescence spectra of Nal:TI measured at $78 \mathrm{~K}$ after the depletion of electron pulse at $t=0 \mathrm{~ns} \mathrm{(1)}$ and $t=100 \mathrm{~ns}$ (2).

irradiation rise component which peaks faster with the increasing temperature, and at temperatures over $180 \mathrm{~K}$ there appears one more exponential decay component with the time constant $\tau_{\text {slow }}$ considerably longer than that of the exponential one $\tau$ which we can see in the expression (1). Further $\tau$ will be referred as $\tau_{\text {fast }}$.

According to [10] the post-irradiation emission rise of Csl:Tl crystal fits a func-

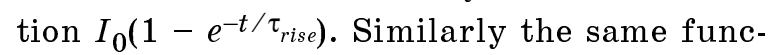
tion can be used for Nal:Tl sample but with the sum of components: $k_{1}$ - fast rise and $k_{2}$ - post-irradiation rise, where $k_{1}+k_{2}=1$. Thus, the rise of Nal:Tl cathodoluminescence pulse fits the following function $I_{0}\left(k_{1}+\right.$ $k_{2}\left(1-e^{-t / \tau_{\text {rise }}}\right)$.

As for the emission decay kinetics at temperature over $180 \mathrm{~K}$, it fits the sum of two exponents:

$$
I(t)=I_{1} \cdot e^{-t / \tau_{\text {fast }}}+I_{2} \cdot e^{-t / \tau_{\text {slow }}}
$$

We also found that the time constants $\tau_{\text {fast }}$, $\tau_{\text {slow }}$ and $\tau_{\text {rise }}$ remain unchanged in spite of the increase of electron beam power density from 0.003 to $0.16 \mathrm{~J} / \mathrm{cm}^{2}$. It means that the rise and decay of the cathodoluminescence pulse are caused by monomolecular processes whose thermal activation energy is determined by the angle of temperature dependences for $\tau_{\text {fast }}$, $\tau_{\text {slow }}$ and $\tau_{\text {rise }}$ time constants which straighten in the Arenius coordinates as shown in Fig. 4 and amounted to $E_{a}\left(\tau_{\text {rise }}\right)=0.07 \pm 0.005 \mathrm{eV}$, $E_{a}\left(\tau_{\text {fast }}\right)=0.026 \pm 0.002 \mathrm{eV}$ and $E_{a}\left(\tau_{\text {slow }}\right)=$ $0.29 \pm 0.01 \mathrm{eV}$, respectively.
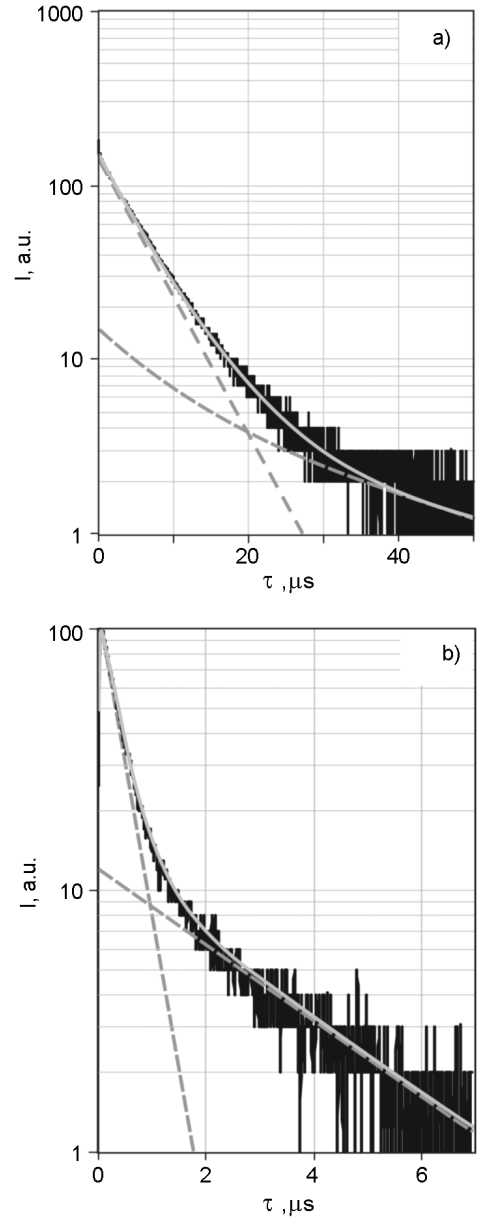

Fig. 2. Cathodoluminescence decay curves of Nal:TI at $430 \mathrm{~nm}$ under $78 \mathrm{~K}$ (a) and $236 \mathrm{~K}$ (b). Broken lines - experimental curves; dash lines - fitting curves; solid lines - the sum of fitting curves.

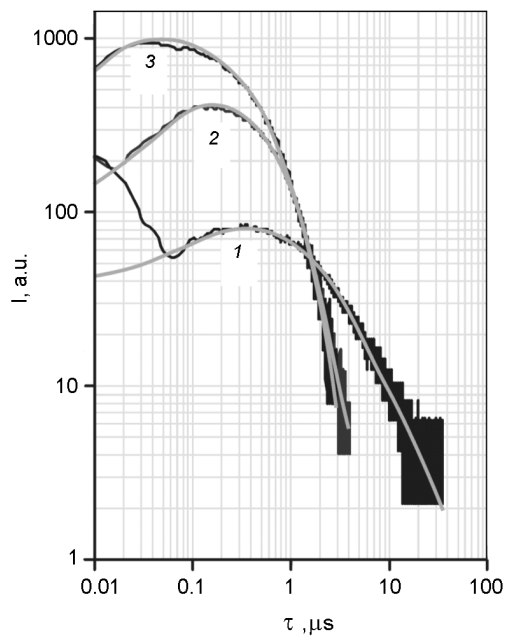

Fig. 3. Cathodoluminescence pulse at $\lambda=425 \mathrm{~nm}$ under temperatures $128 \mathrm{~K}(1), 167 \mathrm{~K}(2)$ and $252 \mathrm{~K}$ (3). Broken lines - experimental curves; solid lines - fitting curves. 


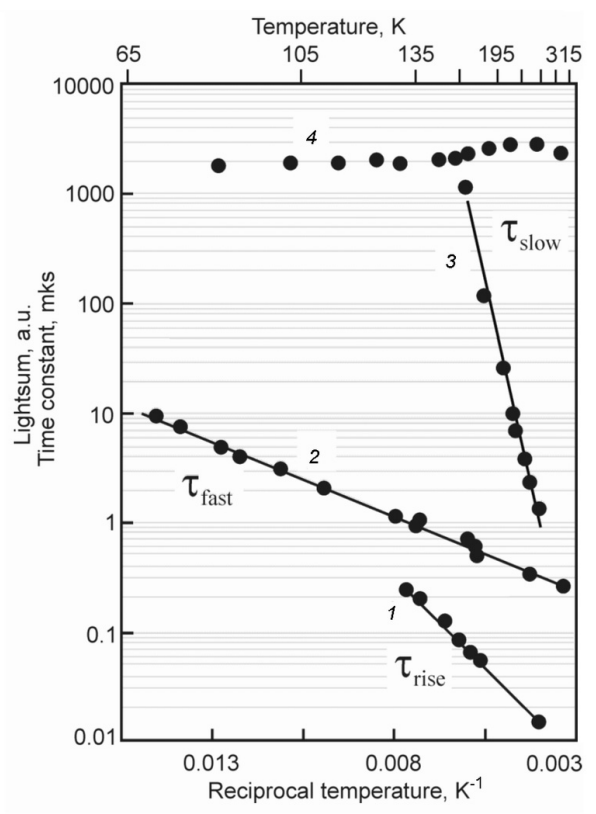

Fig. 4. Kinetics parameters of an emission pulse at $\lambda=425 \mathrm{~nm}$ vs. reciprocal temperature: 1 - rise time constant, 2 - decay time constant of fast component, 3 - decay time constant of slow component. $4-425 \mathrm{~nm}$ emission yield vs. reciprocal temperature.

\section{Discussion} Nal:TI

\subsection{The origin of the $425 \mathrm{~nm}$ emission in}

Almost all researchers [1-9] claim that this $425 \mathrm{~nm}$ emission of $\mathrm{Nal}: \mathrm{Tl}$ is caused by a single $\mathrm{Tl}^{+}$ion transiting from $s p$ to $s^{2}$ electron configuration. According to [1], the electron transition of $\mathrm{Tl}^{+}$ion from ${ }^{3} P_{1}$ to ${ }^{1} S_{0}$ level is responsible for the $425 \mathrm{~nm}$ emission, and the electron population of ${ }^{3} P_{1}$ from ${ }^{3} P_{0}$ level occurs with $0.026 \mathrm{eV}$ activation energy.

Although this inter-combination transition ${ }^{3} P_{1}-{ }^{1} S_{0}$ is forbidden by the selection rules, it is partially allowed in heavy $s^{2}$-ions, and therefore the luminescence must have a long decay. In fact, the experimentally found as well as theoretically calculated life time of ${ }^{3} P_{1}$ state of isolated $\mathrm{Tl}^{+}$ion are 39 ns [11] and $36 \div 81$ ns [12-17], respectively. However, according to our results, about $90 \%$ the initial emission intensity decays with a $12 \mathrm{~ns}$ time constant at $78 \mathrm{~K}$. The time independent emission pulse spectrum as well as the fast decay component with time constant about 12 ns under nonselective excitation argue that the $425 \mathrm{~nm}$ emission is caused by an allowed radiative electron transition of $\mathrm{Tl}^{+}$ion.

The presence of the fast and slow decay components in the emission band of $\mathrm{Tl}^{+}$ions

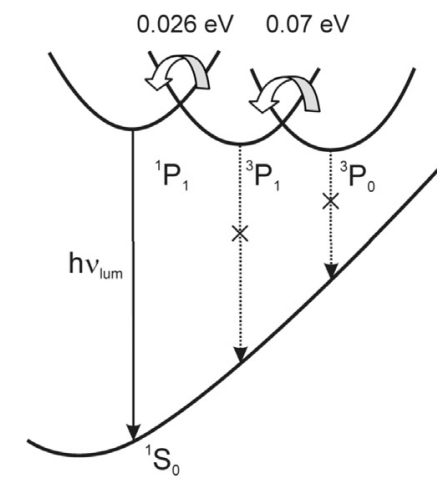

Fig. 5. Scheme of levels for $\mathrm{Tl}^{+}$emission center in Nal:Tl crystal.

excited in the activator absorption region is usually explained within the framework of the three-level electron transition model $[18,19]$, where ${ }^{1} S_{0},{ }^{3} P_{0}$ and ${ }^{3} P_{1}$ are ground, metastable and radiative levels, respectively, with ${ }^{3} P_{1} \rightarrow{ }^{1} S_{0}$ transition being assumed completely allowed. However, such an explanation also contradicts the results of authors $[6,20]$ who studying the photoluminescence of $\mathrm{Nal}: \mathrm{Tl}$ found that at $T \leq 5 \mathrm{~K}$ the $425 \mathrm{~nm}$ emission would not arise in the region of ${ }^{1} S_{0} \rightarrow{ }^{3} P_{1}$ transition ( $A$-band absorption). These contradictions can be overcome within the framework of another model of interlevel transitions of $\mathrm{Tl}^{+}$emission center whose graphic expression in configuration coordinates is shown in Fig. 5 . According to the suggested model, the $425 \mathrm{~nm}$ emission is caused by an allowed transition ${ }^{1} P_{1}-{ }^{1} S_{0}$, whereas the transitions ${ }^{3} P_{1}-{ }^{1} S_{0}$ and ${ }^{3} P_{0}-{ }^{1} S_{0}$ are forbidden. The population of the three $P$ levels of $\mathrm{Tl}^{+}$center in Nal:Tl is initiated by ionizing radiation. The nanosecond decay component is caused by ${ }^{1} P_{1}-{ }^{1} S_{0}$ transition, the microsecond decay component is caused by a phonon assistant ${ }^{3} P_{1}-{ }^{1} P_{1}$ transition which populates ${ }^{1} P_{1}$ level with $0.026 \mathrm{eV}$ activation energy. As for the sub-microsecond rise component at about $130 \mathrm{~K}$, it is caused by phonon assistant ${ }^{3} P_{0}-{ }^{3} P_{1}$ transition which populates ${ }^{3} P_{1}$ level with $0.07 \mathrm{eV}$ activation energy. These transitions are shown in Fig. 5 by arched arrows.

Thus, the presence of the three components in the cathodoluminescence pulse kinetics with the same spectra is due to the excited $\mathrm{Tl}^{+}$ion intracenter transitions which eventually populate ${ }^{1} P_{1}$ level.

\subsection{Nal:TI recombination emission}

The appearance of another slow exponential decay component with $\tau_{\text {slow }}$ at $T>$ 
$160 \mathrm{~K}$ argues for a presence of another thermally activated process responsible for the formation of $\mathrm{Tl}^{+}$centers in ${ }^{1} P_{1}$ state. In spite of the fact that the initial intensity of the slow decay component is considerably lower than that of the fast decay component, the emission yield of the slow decay component becomes higher than the emission yield of the fast decay component at temperatures within 180-250 K (Fig. 2b). The total emission yield at various temperatures is shown in Fig. 4 (curve 4). One can see that with an increasing temperature from $170 \mathrm{~K}$, the total emission yield increases by a factor 1.5 .

It was earlier established that the slow decay component arises in Csl:TI and Csl:Na due to a thermal dissociation of $\left[\mathrm{Tl}^{+}, \mathrm{V}_{k}\right]$ complex [10] and $\left[\mathrm{Na}^{+}, \mathrm{V}_{k}\right.$ ] complex [21], respectively which are also denoted as $V_{k A}$ centers. Unlike $\mathrm{V}_{k}$ centers in Csl lattice, $\mathrm{V}_{k}$ centers in Nal lattice are very unstable. $V_{k}$ centers are set in motion in Nal lattice at $58 \mathrm{~K}[22,23]$, and therefore $\mathrm{Tl}^{+}$ions capture holes to form $\mathrm{T}^{2+}$ but not $\mathrm{V}_{k A}$ centers. Using the time resolved absorption spectroscopy Deich [24] found that a hole escapes from $\mathrm{Tl}^{2+}$ center at temperatures over $150 \mathrm{~K}$ in Nal:Tl.

We calculated that the activation energy for the slow component is $0.29 \mathrm{eV}$ which is higher than the diffusion activation energy of $V_{k}$ centers $(0.18 \mathrm{eV}[22,23]$ or $0.09 \mathrm{eV}$ [24]) in Nal:Tl. Such a big difference in the activation energy allows us to conclude that the slow decay component arises due to a thermal liberation of holes from $\mathrm{T}^{2+}$ centers.

The following expressions describe the recombination process caused by a thermal dissociation of $\mathrm{T}^{2+}$ centers:

$$
\begin{gathered}
\mathrm{T}^{2+}+\ldots+\left.\mathrm{T}\right|^{0} \stackrel{T \geq 170 K}{\longrightarrow} \\
\rightarrow \mathrm{Tl}^{+}+\ldots+e^{+}+\ldots+\left.\mathrm{T}\right|^{0}, \\
\mathrm{Tl}^{+}+\ldots+e^{+}+\ldots+\mathrm{Tl}^{0} \rightarrow \mathrm{Tl}^{+}+\ldots+ \\
+\left(\left.\mathrm{T}\right|^{+}\right)^{*} \rightarrow \mathrm{Tl}^{+}+\ldots+\mathrm{T}^{+}+h v,
\end{gathered}
$$

where $\mathrm{T}^{2+}$ is a hole center; $\mathrm{Tl}^{0}$ is an electron center; $e^{+}$is a hole in the valance band.

In accordance with the formal kinetics law, the slow decay hyperbolic component with an approximation index 2 (see equation 1 ) is expected to correspond to the formation of excited $\mathrm{Tl}^{+}$centers due to the recombination of $\mathrm{Tl}^{0}$ centers with mobile $\mathrm{V}_{k}$ centers similar to Csl:Na [9, 23]. However, the high conversion efficiency of $\mathrm{Nal}: \mathrm{Tl}$ and its emission decay kinetics with dominating ex- ponential components indicate that there is an energy transfer mechanism which considerably differs from that in Csl:Na.

\subsection{Energy transfer mechanism from} NaI lattice to $\mathrm{Tl}+$ ions

The authors of [6] excited Nal:Tl in the absorption bands of free and self-trapped excitons as well as in the region band-toband transitions at $T=2.4 \mathrm{~K}$ and arrived at the conclusion that the free excitons give their energy to $\mathrm{Tl}^{+}$ions only at low temperatures. In our case the $425 \mathrm{~nm}$ emission yield does not decrease with increasing temperature from 78 to $300 \mathrm{~K}$ as shown in Fig. 4 (curve 4). Therefore we believe that the energy transfer in Nal:Tl is mainly caused by band charge carriers, i.e. conduction electrons and valence band holes, whereas in Csl:T| mainly by localized charge carriers, i.e. $V_{k}$ and $\left.T\right|^{0}$ centers $[21,25,26]$. According to expressions (5) and (6), the excitation mechanism of $\mathrm{Tl}^{+}$center emission in Nal lattice can be either electron- or hole-recombination:

$$
\begin{gathered}
\mathrm{Tl}^{+}+\ldots+e+\ldots+h \rightarrow \\
\rightarrow \mathrm{Tl}^{2+}+e \rightarrow\left(\mathrm{T}^{+}\right)^{*} \rightarrow \mathrm{T}^{+}+h \nu \quad(\mathrm{ERL}), \\
\mathrm{T}^{2+}+\ldots+\left.\mathrm{T}\right|^{0} \stackrel{\mathrm{T \geq 170K}}{\rightarrow} \\
\rightarrow \mathrm{Tl}^{+}+\ldots+h+\ldots+\left.\mathrm{T}\right|^{0} \text { (HRL). }
\end{gathered}
$$

\section{Conclusion}

The $425 \mathrm{~nm}$ emission of $\mathrm{Nal}: \mathrm{Tl}$ crystals at room temperatures is caused by a radiative transition of $\mathrm{Tl}^{+}$ion from ${ }^{1} P_{1}$ to ${ }^{1} S_{0}$ state. The post-irradiation rise of the $425 \mathrm{~nm}$ emission is caused by a transition of $\mathrm{Tl}^{+}$ion from ${ }^{3} P_{0}$ to ${ }^{3} P_{1}$ state; the duration of scintillations is determined by the transtion time from a metastable ${ }^{3} P_{1}$ to a radiative ${ }^{1} P_{1}$ state. In order to design fast scintillators, Nal should be doped with an impurity which has no intercombination transitions.

\section{References}

1. I.K.Plyavin, Opt.Spektr., 7, 71 (1959).

2. M.P.Fontana, W.J.Van Sciver, Phys.Rev., 168, 960 (1968).

3. R.G.Kaufman, W.B.Hadley, H.N.Hersh, IEEE Trans. Nucl.Sci., 17, 82 (1970).

4. H.B.Dietrich, A.E.Purdy, R.B.Murray, R.T.Williams, Phys. Rev.B, 8, 5894 (1973).

5. M.Ishikane, M.Kawanishi, Jap.J.Appl.Phys., 14, 64 (1975).

6. H.Nishimura, T.Kubota, M.Tomura, J.Phys. Soc. Jap., 42, 175 (1977). 
7. B.S.Alexandrov, K.D.Ianakiev, P.B.Littlewood, Nucl.Instr. Meth. Phys. Res. A, 358, 432 (2008).

8. R.G.Deich, M.S.Abdrakhmanov, D.P.Erts, A.P.Kuyanov, Sol.Stat.Com., 80, 63 (1991).

9. K.D.Ianakiev, B.S.Alexandrov, P.B.Littlewood, M.C.Browne, Nucl.Instr. Meth. Phys. Res. A, 607, 432 (2009).

10. L.Trefilova, V.Yakovlev, A.Meleshko, N.Kosinov, Radiat. Meas., 45, 328 (2010).

11. M.Henderson. L.J.Curtis, J.Phys. B:At. Mol. Opt. Phys., 29, L629 (1996).

12. T.Brage, D.S.Leckrone, C.Froese Fischer, Phys. Rev. A, 53, 192 (1996).

13. D.R.Beck, Z.Cai, Phys.Rev.A, 41, 301 (1990).

14. J.Migdalek, W.E.Baylis, J.Phys. B:At.Mol. Phys., 18, 1533 (1985).

15. J.Migdalek, A.Bojara, J.Phys. B:At.Mol.Opt. Phys., 21, 2221 (1988).

16. B.P.Das, M.Idrees, Phys.Rev.A, 42, 6900 (1990).
17. H.S.Chou, K.N.Huang, Phys.Rev.A, 45, 1403 (1992).

18. R.Illingworth, Phys. Rev. V, 236, A508 (1964).

19. M.F.Trinkler, I.K Plyavin, Phys. Stat. Sol., 11, 277 (1965).

20. M.P.Fontana, W.J.Van Sciver, H.Blume, Abstr., Intern. Symposium, Rome, September 23-27 (1968), p.99.

21. V.Yakovlev, L.Trefilova, A.Meleshko, Yu.Ganja, J.Luminescence., 131, 2579 (2011).

22. R.D.Popp, R.B.Murray, J.Phys.Chem.Sol., 33, 601 (1972).

23. D.Shoemaker, Phys. Rev.B, 7, 786 (1973).

24. R.G.Deich, Izvestiya Akademii Nauk Latviiskoi SSR, Seriya Fiz.-Tekh.Nauk, 2, 51 (1981).

25. V.Yakovlev, L.Trefilova, A.Meleshko, J. Luminescence., 129, 790 (2009).

26. E.D.Aluker, R.G.Deich, C.A.Chernov, Problems Atomic Science and Technology, Ser. Phys. Rad.Damages and Rad.Mat.Science, 2, 63 (1982). 